\title{
PELAKSANAAN TUGAS KELUARGA DI BIDANG KESEHATAN: MENGENAL MASALAH HIPERTENSI TERHADAP KEJADIAN HIPERTENSI PADA LANSIA DI KELURAHAN TIMBANGAN KECAMATAN INDRALAYA UTARA KABUPATEN OGAN ILIR
}

\author{
Madepan Mulia \\ Akademi Keperawatan Panca Bhakti Bandar Lampung \\ madefikui@gmail.com
}

\begin{abstract}
ABSTRAK
Hipertensi adalah salah satu penyebab kematian nomor satu secara global yang memerlukan penanggulangan yang baik. Hasil Survei Kesehatan Rumah Tangga (SKRT) tahun 2007 menunjukkan bahwa prevalensi penyakit hipertensi pada lansia di Indonesia cukup tinggi, yaitu 83 per 1.000 anggota rumah tangga. Data dari Dinas Kesehatan Kabupaten Ogan Ilir tahun 2010 menunjukkan bahwa hipertensi merupakan penyakit terbanyak ketiga yang menyerang lansia. Penelitian ini bertujuan untuk mengetahui hubungan pelaksanaan tugas keluarga di bidang kesehatan: mengenal masalah hipertensi terhadap kejadian hipertensi pada lansia. Penelitian ini merupakan penelitian analitik kuantitatif dengan pendekatan cross sectional. Penelitian ini dilakukan terhadap keluarga dengan anggota keluarga lansia yang berusia lebih dari 60 tahun yang tersebar di Kelurahan Timbangan yang berjumlah 94 responden, dengan menggunakan alat bantu kuesioner. Untuk menguji hubungan digunakan analisis menggunakan uji Chi-Square. Hasil penelitian menunjukkan bahwa ada hubungan antara pelaksanaan tugas keluarga di bidang kesehatan: mengenal masalah hipertensi terhadap kejadian hipertensi $(\mathrm{p}=0,000)$. Dari hasil penelitian ini disarankan kepada keluarga agar dapat meningkatkan derajat kesehatan dan mengatasi masalah kesehatan anggota keluarganya, khususnya lansia, dengan meningkatkan pengetahuan terkait penyakit hipertensi pada lansia.
\end{abstract}

Kata kunci: Hipertensi, lansia, tugas keluarga di bidang kesehatan

\section{ABSTRACT}

Hypertension is one of the number one causes of death globally that needs a good response. Results of Household Health Survey (SKRT) in 2007 showed that prevalence of hypertension disease in elderly in Indonesia is quite high, that is 83 per 1,000 household members. Data from the District Health Office Ogan Ilir in 2010 showed that hypertension is the third disease that attacks the elderly. This study aims to determine the relationship of family duties in the field of health: know health problems in the elderly with the incidence of hypertension in the elderly. This research is a quantitative analytical research with cross sectional approach. This study was conducted on families with elderly family members aged over 60 years scattered in the village of Timbangan, which amounted to 94 respondents, using a questionnaire tool. To test the relationship used analysis using Chi-Square test. The results showed that there was a relationship between the implementation of family duty in the field of health: know health problems in the elderly with the incidence of hypertension $(p=0.000)$. From the results of this study suggested to the family in order to improve the degree of health and to overcome the health problems of family members, especially the elderly, by performing family duties in the field of health is to know health problems in the elderly.

Keywords: Hypertension, elderly, family duty in the field of health 


\section{PENDAHULUAN}

Keluarga adalah kumpulan dua orang atau lebih yang hidup bersama dengan keterikatan aturan dan emosional dimana individu mempunyai peran masing-masing yang merupakan bagian dari keluarga. Keluarga merupakan unit pelayanan dasar di masyarakat yang juga merupakan perawat utama dalam anggota keluarga. Keluarga dipandang sebagai suatu sistem, dimana keluarga mempengaruhi seluruh keluarga dan sebaliknya keluarga mempengaruhi status kesehatan anggota keluarga yang lain (Friedman, 1998).

Dalam upaya peningkatan derajat kesehatan dan mengatasi masalah kesehatan anggota keluarganya, keluarga harus mampu melaksanakan fungsi perawatan kesehatan keluarga. Berdasarkan hasil penelitian menunjukkan bahwa ada hubungan pelaksanaan fungsi perawatan kesehatan keluarga pada keluarga yang mempunyai anak usia 0-4 tahun dengan frekuensi kejadian ISPA dengan nilai $\mathrm{p}$ value $0,030(\alpha<0,05)$ (Khodariyah, 2009). Fungsi perawatan kesehatan keluarga dapat berfungsi dengan baik jika keluarga dapat melaksanakan tugas keluarga di bidang kesehatan dengan baik pula.

Kesanggupan keluarga melaksanakan fungsi perawatan kesehatan keluarga dapat dilihat dari lima tugas keluarga di bidang kesehatan yang dilaksanakan. Pelaksanaan lima tugas keluarga dibidang kesehatan tersebut meliputi mengenal masalah kesehatan keluarga, mengambil keputusan mengenai tindakan kesehatan yang tepat bagi keluarga, merawat keluarga yang mengalami gangguan kesehatan, memodifikasi lingkungan keluarga untuk menjamin kesehatan keluarga dan memanfaatkan fasilitas pelayanan kesehatan di sekitarnya bagi keluarga (Setyowati, 2008).

Pelaksanaan tugas keluarga di bidang kesehatan sangat diperlukan dalam upaya pencegahan dan mengatasi masalah kesehatan keluarga, khususnya lansia sebagai bagian dari anggota keluarga yang memerlukan perawatan yang lebih ditujukan untuk memenuhi kebutuhan akibat proses penuaan. Salah satunya adalah penanganan terhadap penyakit degeneratif yang banyak diderita oleh lansia yang sering menimbulkan kecacatan (Mubarak, 2010).

Persentase lima penyakit degeneratif utama yang banyak diderita oleh lansia di
Indonesia adalah anemia sebesar 50\%, penyakit kardiovaskuler sebesar 29,5\%, infeksi saluran pernafasan sebesar 12,2\%, penyakit kanker sebesar $12,2 \%$ dan penyakit TBC 11,5\% (Riskesdas, 2013). Salah satu penyakit degeneratif pada lansia yang menyerang sistem kardiovaskular adalah hipertensi atau peningkatan tekanan darah. Hipertensi adalah kondisi medis ketika seseorang mengalami peningkatan tekanan darah di atas normal dalam jangka waktu yang lama (Sudarmoko, 2010). Seorang lansia dikatakan menderita hipertensi bila tekanan darahnya mencapai 160/90 mmHg (Smeltzer, 2002).

Peningkatan tekanan darah hingga mencapai 160/90 $\mathrm{mmHg}$ pada lansia dipengaruhi oleh beberapa faktor. Faktorfaktor yang meningkatkan risiko hipertensi adalah obesitas dan kebiasaan merokok (Mansjoer, 2001). Hasil analisis faktor risiko yang berkaitan dengan kejadian hipertensi pada lansia di wilayah kerja Puskesmas Kroya Kabupaten Cilacap tahun 2005, diperoleh hasil bahwa faktor risiko kejadian hipertensi pada lansia meliputi kebiasaan merokok, kebiasaan minum kopi, konsumsi daging berlemak, faktor genetik dan stress psikologis. Kebiasaan hidup yang baik seperti mengurangi kebiasaan merokok, pola makan yang berlebihan, konsumsi lemak berlebih serta kebiasaan hidup yang tidak sehat merupakan cara yang paling tepat dalam upaya mengurangi peningkatan kejadian hipertensi (Sulistiani, 2005).

Prevalensi penyakit hipertensi pada lansia di Indonesia cukup tinggi, yaitu 83 per 1.000 anggota rumah tangga (Riskesdas, 2013). Di Provinsi Sumatera Selatan, prevalensi hipertensi pada tahun 2008 sebesar 9,17\% dan di Kabupaten Ogan Ilir, prevalensi hipertensi pada tahun 2010 sebesar 15,9\%. Data dari Dinkes Ogan Ilir tahun 2010 menunjukkan bahwa hipertensi merupakan penyakit terbanyak ketiga yang menyerang lansia setelah penyakit degeneratif lainnya (rematik dan ISPA).

Berdasarkan hasil studi pendahuluan yang dilakukan di Puskesmas Timbangan, didapatkan data bahwa penyakit tidak menular terbanyak pada lansia adalah penyakit hipertensi. Angka kunjungan penderita hipertensi ke Puskesmas Timbangan adalah sebesar 38,6\% yang menempati posisi lebih tinggi daripada angka kejadian hipertensi di 
Kabupaten Ogan Ilir yang hanya sebesar $15,9 \%$. Selain itu, kunjungan penderita hipertensi ke Puskesmas Timbangan lebih banyak berasal dari kelompok lansia yaitu berumur lebih dari 60 tahun sehingga peneliti mengambil penderita hipertensi dari kelompok lansia.

Berdasarkan studi pendahuluan yang dilakukan di Kantor Kelurahan Timbangan, didapatkan data bahwa jumlah lansia di Kelurahan Timbangan adalah sebesar 48\% dari seluruh jumlah lansia yang berada di wilayah kerja Puskesmas Timbangan. Hal ini menunjukkan bahwa hampir sebagian dari seluruh lansia yang berada di wilayah kerja Puskesmas Timbangan berada di Kelurahan Timbangan, sehingga peneliti memilih Desa Kelurahan Timbangan sebagai tempat penelitian.

Berdasarkan hasil wawancara kepada keluarga di Kelurahan Timbangan, didapatkan bahwa 4 dari 5 keluarga mengatakan masih sering mengkonsumsi makanan yang mengandung tinggi lemak dan kolesterol, seperti makanan yang bersantan dan gorengan. Keluarga pun masih sering mengkonsumsi makanan yang asin-asin dan seringkali menambahkan banyak garam dan gula ke dalam makanannya yang dapat berpotensi meningkatkan tekanan darah dan risiko obesitas. Selain itu, kebiasaan mengkonsumsi makanan siap saji yang tinggi akan natrium dan Monosodium Glutamate (MSG) atau sering disebut penyedap rasa pun masih sering dilakukan.

Dipihak lain, perawat sebagai peneliti bertanggung jawab untuk memberikan bantuan keperawatan dalam upaya penyembuhan dan pencegahan terjadinya hipertensi pada lansia. Peran perawat sebagai peneliti adalah mengembangkan keperawatan keluarga dan memberikan gambaran baru kepada keluarga tentang pemenuhan kebutuhan perawatan serta pengenalan kebutuhan lansia dengan hipertensi sehingga diperoleh satu kesatuan antara tercapainya peran keluarga dalam pelaksanaan tugas keluarga dibidang kesehatan dan terpenuhinya kebutuhan perawatan yang diperlukan lansia yang dirawat di dalam kehidupan keluarga.

\section{METODE}

Penelitian ini merupakan penelitian analitik kuantitatif dengan desain cross sectional. Populasi yang digunakan dalam penelitian ini adalah sebanyak 123 keluarga (yang melaksanakan tugas keluarga dibidang kesehatan yaitu istri atau anak perempuan), dengan anggota keluarga lansia yang berusia lebih dari 60 tahun. Metode yang digunakan adalah purposive sampling. Sampel sebanyak 94 keluarga dengan anggota keluarga lansia yang yang berusia lebih dari 60 tahun

\section{HASIL}

Hubungan antara kemampuan keluarga mengenal masalah hipertensi pada lansia dengan kejadian hipertensi pada lansia Di Kelurahan Timbangan Kecamatan Indralaya Utara Kabupaten Ogan Ilir dapat dilihat pada tabel 1

\section{Tabel 1 Hubungan Kemampuan Keluarga Mengenal Masalah Hipertensi Pada Lansia Dengan Kejadian Hipertensi Pada Lansia}

\begin{tabular}{|c|c|c|}
\hline $\begin{array}{c}\text { Mengenal } \\
\text { masalah } \\
\text { hipertensi pada } \\
\text { lansia }\end{array}$ & P Value & $\begin{array}{c}\text { OR } \\
(95 \% \mathrm{CI})\end{array}$ \\
\hline Baik & \multirow[b]{2}{*}{0,028} & \multirow{2}{*}{$\begin{array}{c}2,778 \\
(1,199-6,436)\end{array}$} \\
\hline $\begin{array}{l}\text { Tidak Baik } \\
\text { Total }\end{array}$ & & \\
\hline
\end{tabular}

Dari hasil tabel silang antara kemampuan keluarga mengenal masalah hipertensi pada lansia dengan kejadian hipertensi pada lansia di Kelurahan Timbangan Kecamatan Indralaya Utara Kabupaten Ogan Ilir yang diperlihatkan pada tabel 1.1, didapatkan hasil bahwa keluarga yang mengenal masalah hipertensi pada lansia dengan baik maka kejadian hipertensi pada lansia akan cenderung lebih sedikit yaitu sebanyak 17 lansia (40,5\%) dan keluarga yang tidak baik dalam mengenal masalah hipertensi pada lansia maka kejadian hipertensi pada lansia akan cenderung lebih banyak yaitu sebanyak 34 lansia $(65,4 \%)$.

Hasil uji statistik dengan Chi-square menunjukkan nilai p value $=0,028(\alpha<0,05)$, maka dapat disimpulkan bahwa terdapat hubungan bermakna (signifikan) antara kemampuan keluarga mengenal masalah hipertensi pada lansia dengan kejadian hipertensi pada lansia di Kelurahan Timbangan Kecamatan Indralaya Utara Kabupaten Ogan Ilir. Dari hasil analisis diperoleh pula nilai $\mathrm{OR}=2,778$, artinya 
keluarga yang tidak baik dalam mengenal masalah hipertensi pada lansia berpeluang 2,778 kali untuk terjadinya hipertensi pada lansia.

\section{PEMBAHASAN}

Dari hasil penelitian didapatkan bahwa keluarga yang mengenal masalah hipertensi pada lansia dengan baik maka kejadian hipertensi pada lansia akan cenderung lebih sedikit yaitu 40,5\% dan keluarga yang tidak baik dalam mengenal masalah hipertensi pada lansia maka kejadian hipertensi pada lansia akan cenderung lebih banyak yaitu $65,4 \%$. Hasil uji statistik dengan Chi-square menunjukkan nilai $\mathrm{p}$ value $=0,028(\alpha<0,05)$, maka dapat disimpulkan bahwa terdapat hubungan bermakna antara kemampuan keluarga mengenal masalah hipertensi pada lansia dengan kejadian hipertensi pada lansia di Kelurahan Timbangan Kecamatan Indralaya Utara Kabupaten Ogan Ilir.

Hasil penelitian mengenai hubungan antara pengetahuan keluarga tentang perawatan hipertensi dengan kejadian hipertensi pada usila di Desa Bendo Wilayah Kerja Puskesmas Bendo Magetan Jawa Timur dengan nilai $\mathrm{p}$ value $=0,001(\alpha<0,05)$, menyatakan bahwa terdapat hubungan bermakna antara pengetahuan keluarga tentang perawatan hipertensi dengan kejadian hipertensi (Khotijah, 2008).

Tingkat pengetahuan keluarga terkait konsep sehat sakit akan mempengaruhi perilaku keluarga dalam menyelesaikan masalah kesehatan keluarga (Mubarak, 2010). Pengetahuan keluarga yang baik mengenai pencegahan, penanganan dan perawatan terhadap lansia yang menderita hipertensi akan mempengaruhi kejadian hipertensi pada lansia. Dengan mempunyai bekal pengetahuan yang memadai mengenai hipertensi, maka keluarga bisa menyusun suatu rencana dan tindakan nyata untuk memberikan suatu upaya perawatan yang tepat. Semakin baik pengetahuan keluarga mengenai hipertensi, upaya perawatan yang diberikan akan semakin baik sehingga masalah hipertensi pada lansia akan semakin mudah diatasi. Mengenal dan mengetahui jenis penyakit pada tingkat awal serta mengadakan pengobatan yang tepat dan segera bertujuan untuk mencegah terjadinya kecacatan akibat suatu penyakit, penularan dan penyembuhan yang sempurna (Entjang, 2000).
Hasil analisis univariat memperlihatkan sebanyak 52 keluarga $(55,3 \%)$ tidak baik dalam mengenal masalah hipertensi pada lansia. Dapat disimpulkan bahwa pengetahuan keluarga mengenai penyakit hipertensi, meliputi pengertian, makanan yang baik untuk menurunkan dan mengontrol tekanan darah, makanan yang harus dihindari, tanda dan gejala, serta faktor resiko masih kurang baik. Menurut analisis peneliti, kurangnya pengetahuan keluarga mengenai hipertensi disebabkan oleh tingkat pendidikan keluarga yang rendah, yaitu $47,9 \%$ hanya tamatan SD. Pengetahuan dapat diperoleh dengan pendidikan melalui proses belajar (Notoatmodjo, 2010).

Pendidikan seseorang dapat mempengaruhi tingkat pengetahuan seseorang. Seseorang dengan jenjang pendidikan tinggi akan jauh lebih baik pola pikirnya dibandingkan dengan yang berpendidikan rendah. Dalam hal ini, keluarga dengan latar pendidikan tinggi akan memiliki kemampuan yang lebih cepat dalam menyerap informasi, khususnya informasi mengenai kesehatan. Pendidikan merupakan suatu proses pembelajaran bagi individu, khususnya keluarga, untuk mencapai pengetahuan dan pemahaman yang lebih tinggi terhadap suatu objek tertentu. Semakin tinggi tingkat pendidikan seseorang, makin mudah pula seseorang menerima informasi sehingga makin banyak pula pengetahuan yang dimiliki sebaliknya pendidikan yang kurang akan menghambat perkembangan sikap seseorang terhadap nilai-nilai yang baru diperkenalkan (Notoatmodjo, 2010).

Selain rendahnya tingkat pendidikan keluarga, kurangnya keluarga dalam mengenal masalah hipertensi pada lansia juga disebabkan oleh kurang terpajan informasi dan kurangnya pengalaman dari keluarga. Faktor-faktor yang mempengaruhi pengetahuan adalah tingkat pendidikan, informasi dan pengalaman. Informasi yang dimaksud disini adalah informasi terkait cara pencegahan, cara mengendalikan tekanan darah sehingga menjadi normal dan masalah pengobatan (Notoatmodjo, 2010). Salah satu penyebab kurangnya informasi yang didapatkan keluarga adalah kurang aktifnya petugas kesehatan dalam melakukan promosi kesehatan yaitu dengan mengadakan penyuluhan pada kelompok yang berisiko 
terkena hipertensi maupun pada kelompok yang telah menderita hipertensi.

Faktor pengalaman dari keluarga juga menjadi salah satu faktor penyebab kurangnya pengetahuan pada keluarga. Hal ini sesuai dengan data yang didapatkan dari hasil penelitian bahwa sebagian besar keluarga yang melaksanakan tugas keluarga dibidang kesehatan, yaitu $38,3 \%$ berumur 31-40 tahun. Pengalaman adalah salah satu faktor yang mempengaruhi pengetahuan (Notoatmodjo, 2010). Pengalaman disini berkaitan dengan umur, maksudnya semakin bertambah tua seseorang maka pengalaman yang didapatkan akan semakin luas. Khususnya pengalaman keluarga dalam upaya memberikan perawatan terhadap lansia yang menderita hipertensi.

Seperti yang telah dijelaskan sebelumnya bahwa kurang aktifnya petugas kesehatan dalam melakukan promosi kesehatan adalah salah satu penyebab kurangnya pengetahuan pada keluarga. Akan tetapi, kurang aktifnya petugas kesehatan dalam melakukan promosi kesehatan bukanlah satu-satunya penyebab kurangnya pengetahuan pada keluarga. Kurangnya perhatian keluarga terhadap keadaan kesehatan anggota keluarga dapat juga menyebabkan kurangnya pengetahuan mengenai kesehatan. Dengan rendahnya tingkat pendidikan, kurangnya pengalaman dan kurang aktifnya petugas kesehatan dalam melakukan promosi kesehatan, maka sebenarnya tingkat pengetahuan dapat ditingkatkan melalui peran aktif keluarga dalam mencari informasi mengenai kesehatan. Informasi terkait kesehatan dapat keluarga dapatkan tidak hanya melalui petugas kesehatan, ada media lain yang bisa dimanfaatkan, seperti televisi, radio, koran ataupun majalah kesehatan.

Perawat pada fase ini berperan penting dalam upaya promosi kesehatan yaitu dengan mengadakan penyuluhan kesehatan untuk meningkatkan pengetahuan keluarga. Kegiatan sebaiknya tidak hanya terbatas pada pemberian penyuluhan kesehatan di puskesmas atau tempat pelayanan kesehatan saja namun petugas kesehatan diharapkan dapat melakukan kunjungan rumah berkala dalam rangka meningkatkan pengetahuan keluarga.

\section{KESIMPULAN}

Ada hubungan bermakna ( $\mathrm{p}$ value $=$ $0,028$ berarti $\mathrm{p}$ value $<0,05)$ antara kemampuan keluarga dalam mengenal masalah hipertensi pada lansia dengan kejadian hipertensi pada lansia di Kelurahan Timbangan Kecamatan Indralaya Utara Kabupaten Ogan Ilir.

\section{SARAN}

Hasil penelitian ini diharapkan dapat memberikan informasi atau gambaran kepada masyarakat, khususnya keluarga mengenai pentingnya pelaksanaan tugas keluarga di bidang kesehatan: mengenal masalah hipertensi dalam upaya penyembuhan dan pencegahan terjadinya hipertensi pada lansia.

\section{DAFTAR PUSTAKA}

Entjang, Indan. (2000). Ilmu Kesehatan Masyarakat. Bandung: PT Citra Aditya Bakti.

Friedman, Marylin M. (1998). Keperawatan Keluarga: Teori dan Praktek_edisi 3. Jakarta: EGC.

Khodariyah, Laelatul. (2009). Hubungan

Pelaksanaan Fungsi Perawatan

Kesehatan Keluarga Pada Keluarga Yang Mempunyai Anak Usia 0-4 Tahun Dengan Frekuensi Kejadian Ispa Di Desa Tanggung Kecamatan Tanggungharjo Kabupaten Grobogan. http://digilib.unimus.ac.id/, diperoleh tanggal 16 Maret 2013.

Khotijah, Siti. (2008). Hubungan Antara Pengetahuan Keluarga Tentang Perawatan Hipertensi Dengan Kejadian Hipertensi Pada Usila Di Desa Bendo Wilayah Kerja Puskesmas Bendo Magetan Jawa Timur.https://skripsistikes.wordpress.co m, diperoleh tanggal 9 Juli 2013.

Mansjoer, Arif et al. (2001). Kapita Selekta Kedokteran_edisi 3. Jakarta: Media Aesculapius.

Mubarak, Wahit Iqbal et al. (2010). Ilmu Keperawatan Komunitas: Konsep dan Aplikasi. Jakarta: Salemba Medika.

Notoatmodjo, Soekidjo. (2010). Ilmu Perilaku Kesehatan. Jakarta: PT Rineka Cipta.

Riset Kesehatan Dasar. (2013). Jakarta: Badan Penelitian dan Pengembangan Kesehatan, Departemen Kesehatan Republik Indonesia 
Setyowati, Sri \& Murwani, A. (2008). Asuhan Keperawatan Keluarga: Konsep dan Aplikasi Kasus. Yogyakarta: Mitra Cendikia.

Smeltzer, S. C., \& Bare, B. G. (2002). Keperawatan Medikal-Bedah_Volume 3. Jakarta: EGC.

Sudarmoko, Arief. (2010). Tetap Tersenyum Melawan Hipertensi. Yogyakarta: Atma Media Press.

Sulistiani, Widi. (2005). Analisis Faktor Risiko Yang Berkaitan Dengan Kejadian Hipertensi Pada Lansia Di Wilayah Kerja Puskesmas Kroya I Kabupaten Cilacap. http://eprints.undip.ac.id/5212/1/2438.p df, diperoleh tanggal 16 Maret 2013. 